\title{
Tröskelbegrepp inom grammatiken ${ }^{\mathrm{I}}$
}

\author{
Gunlög Josefsson*, Katarina Lundin \\ Nordiska språk, Språk- och litteraturcentrum, Lunds universitet
}

\begin{abstract}
I vår artikel vill vi med utgångspunkt i tröskelbegreppet (Perkins 1999) undersöka moment inom grammatiken som är svåra för studenterna att tillägna sig, men som är helt avgörande för förståelse och progression. I första hand utgår vi från en analys av underkända tentamina i ämnet svenska. Analysen pekar ut tre problemområden: svårigheter med att skilja mellan betydelse, form och funktion, med att skilja mellan en linjär och en hierarkisk dimension samt med att korrekt avgränsa satser och fraser. En del av problemen med grammatik verkar kunna härledas till komplexiteten i processandet och krav på koncentration under längre tidsföljd - lite förenklat att studenterna måste kunna ha flera bollar i luften samtidigt och ha det under en ganska lång tid. Vi diskuterar även gränsdragningen mellan vad som är sund pedagogisk anpassning och vad som är rimliga krav på studenterna att hitta egna strategier för sitt arbete och sitt lärande.
\end{abstract}

Nyckelord: tröskelbegreppet, grammatik, grammatikdidaktik, språklig hierarki, satsbegreppet, frasbegreppet

\section{INTRODUKTION}

Grammatik är svårt att lära sig, tycker många. En stor grupp studenter förefaller ha ett fragmentariskt eller vad man kan kalla associativt förhållningssätt till grammatik. De känner igen en del termer, kan vissa delar mer eller mindre ytligt, men saknar både djupare förståelse och systematik inom området. Med utgångspunkt i tröskelbegreppet (Threshold Concepts, se t.ex. Meyer \& Land 2003) vill vi i vår artikel undersöka närmare vari svårigheterna med grammatik ligger. ${ }^{2}$ Syftet är att försöka frilägga några tröskelbegrepp, som förefaller svåra för studenterna att tillägna sig men som är avgörande för grammatisk förståelse. I förlängningen finns förstås också ett pedagogiskt syfte: att försöka utveckla grammatikundervisningen, så att studenterna kan nå djupare i sitt analytiska tänkande.

1 Först och främst vill vi tacka våra studenter som har ställt upp och hjälpt oss med data i vårt projekt. Utan er hade aldrig projektet kunnat bli av! Vi riktar ett även varmt tack till Språk- och litteraturcentrum, Lunds universitet, som har stöttat med utvecklingsmedel. Ett tack också till deltagare i Forskarseminariet i nordiska språk och i Language Acquisition Seminar vid Språk- och litteraturcentrum, Lunds universitet, samt deltagare i Grammatikundervisningsworkshopen vid Institutionen för svenska språket, Göteborgs universitet i maj 20I7, för värdefulla synpunkter. Ett stort tack riktas slutligen också till en anonym reviewer vid Högre studier för ytterst värdefulla synpunkter på en tidigare version av artikeln. Alla kvarvarande fel och brister är vårt eget ansvar.

2 Undersökningen som ligger till grund för artikeln är ett första led i ett större pedagogiskt utvecklingsprojekt, Analytiskt tänkande och grammatikundervisningens utmaning.

\footnotetext{
* Författarkontakt: gunlog.josefsson@nordlund.lu.se

Artiklar och reflektioner är kollegialt granskade. Övriga bidragstyper granskas av redaktionen. Se www.hogreutbildning.se ISSN 2000-7558

(C) 2017 Gunlög Josefsson \& Katarina Lundin. This is an Open Access article distributed under the terms of the Creative Commons Attribution-NonCommercial 4.0 International License (https://creativecommons.org/licenses/by-nc/4.0/), allowing third parties to share their work (copy, distribute, transmit) and to adapt it, under the condition that the authors are given credit, that the work is not used for commercial purposes, and that in the event of reuse or distribution, the terms of this license are made clear.

Citation: Gunlög Josefsson \& Katarina Lundin (2017) «Tröskelbegrepp inom grammatiken», Högre utbildning 7(2), 18-34. http://dx.doi. org/10.23865/hu.v7.1033
} 


\section{TEORETISK BAKGRUND}

Tröskelbegreppet, på engelska the Threshold Concept (se t.ex. Meyer \& Land 2003; 2006) är centralt inom den didaktiska forskningen. Även om termen introducerades av Meyer \& Land är själva tanken inte ny - den sätter namn på en erfarenhet som delas av många lärare och studenter - att det finns vissa centrala begrepp, moment och tankesätt som en individ måste förstå på djupet för att kunna gå vidare i sitt lärande. Meyer \& Land (2003) liknar tröskelbegrepp vid portaler. När man väl har förstått ett tröskelbegrepp öppnar sig nya perspektiv och sätt att tänka som man tidigare helt enkelt inte var förmögen att se eller förstå:
[A threshold concept] represents a transformed way of understanding, or interpreting, or vie- wing something without which the learner cannot progress. /---/ This transformation may be sudden or it may be protracted over a considerable period of time, with the transition to understanding proving troublesome. Such a transformed view or landscape may represent how people 'think' in a particular discipline, or how they perceive, apprehend, or experience particular phenomena within that discipline (or more generally). (Meyer \& Land 2003, s. 4I2)

Perkins diskuterar tröskelbegreppet i en artikel från 1999, även om han inte använder just den termen, och beskriver denna typ av "konceptuella portaler" med fyra adjektiv: transformative, integrative, irreversible and troublesome. Transformative syftar på att tillägnandet av ett tröskelbegrepp innebär en avgörande kvalitativ förändring i hur en inlärare uppfattar en företeelse. Integravite syftar på att tillägnandet av ett tröskelbegrepp synliggör tidigare dolda eller ickeuppenbara samband, vilket kastar ljus över större områden än just det som det aktuella tröskelbegreppet handlade om. Irreversible syftar på att en inlärare inte kan tänka bort eller glömma de insikter man fått - man har fått en ny blick, ett nytt seende. Troublesome syftar inte bara på att ett tröskelbegrepp är svårt att tillägna sig i största allmänhet och att inläraren måste anstränga sig för att erövra denna kunskap, utan också på att den kunskap som tröskelbegreppet innebär är något som kanske kan liknas vid förfrämligande; det är "knowledge that is 'alien', or counterintuitive, ritualised, inert, tacit or even intellectually absurd at face value" (Land, Meyer \& Smith 2008, s. x; se även Perkins 1999, s. I0).

Perkins (2008) diskuterar tröskelbegreppets relation till tre olika typer av kunskap, eller snarare djup av kunskap: possessiv, performative och proactive knowledge. Possessiv kunskap handlar om att memorera fakta och applicera denna på ett enkelt ("straightforward") sätt. Performativ kunskap når djupare och innebär att kunskapen kan tillämpas inom en given kontext: "When students recognise that they can reason within disciplines and contexts, knowledge takes on a more active form, the performative conception" (Perkins 2008, s. 6). Proaktiv kunskap, slutligen, går kvalitativt bortom den possessiva och den performativa, även om den förutsätter eller innesluter de båda andra. I sin beskrivning av vad proaktiv kunskap är använder Perkins termen deployment 'utvidgning, extension'. Detta syftar på att proaktiv kunskap når ut över sig själv och gör det möjligt för individen att applicera eller transformera kunskapen på nya företeelser i helt nya fält. Proaktiv kunskap ger blick eller ett nytt seende för när kunskap blir applicerbar i ett nytt kunskapsområde.

Perkins identifierar proaktiv kunskap med vad som i andra teoretiska ramverk samlas under begreppet deep approaches (som står i motsättning till surface approaches), så t.ex. i Marton \& Säljö 1976, Säljö 1979 och Marton, Hounsell \& Entwistle 1997. Enligt Säljö (1979) karakteriseras deep approach av att individen just ser saker och ting på ett annorlunda sätt. 
Tröskelbegreppet och idén om den proaktiva kunskapen är, enligt Perkins (2008, s. I2), "natural partners"; med syftning på portalmetaformen (se ovan) skriver han "threshold concepts open up a portal in a domain, affording access to a newly integrative way of thinking about whole swathes of its territory". Perkins understryker vikten av att undervisning centreras kring tröskelbegrepp, just för att detta ger förutsättning för tillägnande av proaktiv kunskap: "On the one hand, instructional attention to threshold concepts seems likely to foster proactive knowledge. On the other, the concept of proactive knowledge has something of a threshold character, with the potential to reorganise in significant ways how we think about teaching and learning" (s. 4).

Orsini-Jones (2008) presenterar i samlingsvolymen Threshold concepts within the disciplines (Land, Meyer \& Smith, red., 2008) bland annat en studie om tröskelbegrepp inom högskolegrammatiken. Hennes undersökning bygger på intervjuer av studenter som studerar en grammatikmodul vid Coventry University i Storbritannien. Den grammatiska analysmodell man utgick från där var något annorlunda än i vår undersökning, nämligen funktionell grammatik, enligt Halliday 1985, men studien är på många sätt relevant för oss.

Orsini-Jones (2008) liknar studenternas inlärningsväg under den termin som de studerar grundläggande grammatik vid Coventry University vid Dantes väg från Inferno till Paradiso. En del av de problem som de upplever på denna mödosamma vandring härleder hon till tidigare, felaktig inlärning. Annat verkar vara svårt av andra skäl. Det som studenterna upplevde som allra svårast ("troublesome") i hennes undersökning var det hon benämner rank-scale. Rank-scale definieras som principen att mindre språkliga enheter, till exempel morfem, kan fogas samman till större enheter, ord, som i sin tur kan fogas samman till större enheter, fraser. Den största enheten är satsen. I begreppet rank-scale tycks också ingå principen att ord och fraser består av huvudled/huvudord och bestämningar. För att rätt kunna kategorisera ett ord eller en fras måste man kunna identifiera huvudleden/huvudordet.

Av de språkliga kategorierna morfem, ord, fras och sats upplevde studenterna kategorierna morfem, fras och sats som svårast, d.v.s. alla språkliga nivåer utom ord. (Inom parentes kan sägas att det kanske inte är så förvånande att studenterna inte fann ordbegreppet så svårt.) Intressanta reflektioner som studenterna i Orsini-Jones undersökning gör är att de känner att de förstår vissa saker i undervisningssituationen, men att de känner sig förlorade eller vilsna när de ska applicera dessa på egen hand. Vidare upplever de att de ibland tycker sig förstå en kort stund, men sedan "glömmer": "You know I understood the concept for about, let's say Io seconds, yes yes, I got that and then suddenly, no no, I didn't get that" (Orsini-Jones 2008, s. 218). Det faktum att studenterna både tycker att begreppen morfem, fras och sats är svåra i sig - och hur de hänger ihop med varandra - tyder, enligt Orsini-Jones, på att "each of these individual grammar categories is a self-standing threshold concept, which, once mastered, opens up a new door into the next one" (s. 219). Orsini-Jones föreslår även att hela konceptet rank-scale är ett tröskelbegrepp som i sig innehåller de "inbäddade" tröskelkoncepten morfem, fras och sats.

Orsini-Jones recept för lyckad grammatikundervisning är en kombination av studentcentrerad aktivitet, integrerad och effektiv användning av inlärningsteknologi samt "constructivist teaching methods" (Orsini-Jones 2008, s. 222).

Det grammatikprojekt som ligger bakom Orsini-Jones rapport gav uppenbarligen effekt, även om hon noterar att det inte passade alla studenter. Enligt Orsini-Jones berodde detta på att projektet krävde mer kognitivt engagemang av studenterna än vad alla var beredda att lägga ner. 
Det ska noteras att studenterna i Orsini-Jones projekt hade ett helt år på sig att förstå de grundläggande grammatiska begreppen. (Hur mycket undervisningstid de fick framgår inte.) I det grammatikprojekt som vi rapporterar om i denna artikel har studenterna en kursmodul om 7,5 hp, det vill säga ca 4,5 veckor, på sig att tillägna sig samma insikter. Tilläggas ska att denna tidsram motsvarar standarden inom den svenska högskolevärlden.

\section{MATERIAL OCH METOD}

I vår studie utgår vi i första hand från en analys av tentamina i svensk grammatik. Vi har i detalj analyserat underkända tentor och omtentor från hösten 20I5 och våren 20I6. De analyserade tentorna kommer dels från en fristående kurs i grammatik inom grundutbildningen i svenska vid Lunds universitet, dels från motsvarande kurs på ämneslärarutbildningen i svenska vid Lunds universitet. I relevanta delar är innehåll och mål för de båda kurserna detsamma. I de underkända tentorna delades felen upp i två grupper. I den första gruppen hamnade enkla fel, t.ex. att studenterna inte kände till enskilda grammatiska termer eller gjorde enkla klassificeringsfel. Denna typ av fel kan möjligen bero på bristande arbetsinsats, och vi fördjupade oss inte i dem. I den andra gruppen hamnade fel som vi bedömde som allvarligare och som handlade om brister i tanke- och analysprocessen. Det ska tilläggas att analysen naturligtvis inte gjordes förutsättningslöst, utan att vi bar med oss våra förkunskaper om vad studenter brukar tycka är svårt. Djupanalysen av felen gav oss dock förvånande många nya insikter om svårigheterna med grammatik.

Vi har även intervjuat studenter, närmare bestämt en fokusgrupp som utbildar sig till svensklärare. Till sist har vi använt oss av loggboksanteckningar som studenterna i grundutbildningen i svenska förde under kursens gång. Vår studie har i första hand en kvalitativ ansats.

Den modell för grammatisk analys som vi har använt faller inom ramen för vad som skulle kunna karakteriseras som traditionell grammatik, som den presenteras t.ex. i Svenska Akademiens grammatik (Teleman et al. 1999). Den mer detaljerade utformningen av analysen bygger på Josefsson (2009) och Lundin (20I4; 20I5).

\section{TRE GRAMMATISKA TRÖSKELBEGREPP}

Resultaten av analysen av de underkända tentorna och omtentorna pekar ut några olika men troligen sammanlänkade tänkande- och förståelseproblem, som alla på något sätt utgör förutsättningar för en grammatisk analys och som vi menar kan förstås som tröskelbegrepp.

I de följande underavsnitten ligger fokus på svårigheter att skilja mellan betydelse, form och funktion, svårigheter att skilja mellan språkets linjära och hierarkiska dimension samt problem med att avgränsa fraser och satser.

\section{Svarigheten att skilja mellan betydelse, form och funktion}

En fundamental princip för mänskligt språk är att det har olika dimensioner - en språklig sekvens kan analyseras i termer av betydelse, i termer av form, det vill säga inre uppbyggnad, och i termer av funktion, det vill säga hur enheten fungerar i relation till andra språkliga enheter runt omkring. Detta kan verka abstrakt men är egentligen intuitivt. Låt oss se på ett exempel. 
En sekvens som en röd ros kan sättas in i en mening, till exempel: Jag har köpt en röd ros. Den mest omedelbara aspekten är betydelsen, som i det här fallet kan beskrivas som ett tankeinnehåll, ett koncept - vi vet alla vad en röd ros är. Form handlar om den inre uppbyggnaden av ordsekvensen en röd ros; ros är huvudord i vad som kallas för en fras, en enhet där de tre orden en + röd + ros hör tätare samman med varandra än t.ex. med ordet köpt, som kommer omedelbart före. Huvudordets ordklass, i det här fallet att ros är ett substantiv, gör en röd ros till en substantivfras, med en mer teknisk term en nominalfras. Funktion, slutligen, handlar om vilken satsdel nominalfrasen en röd ros har i just den aktuella satsen. Satsdelsbegreppet torde vara bekant för de flesta, och det här fallet är en röd ros objekt, närmare bestämt direkt objekt, som har en relation till predikatet har köpt och subjektet jag.

(I)

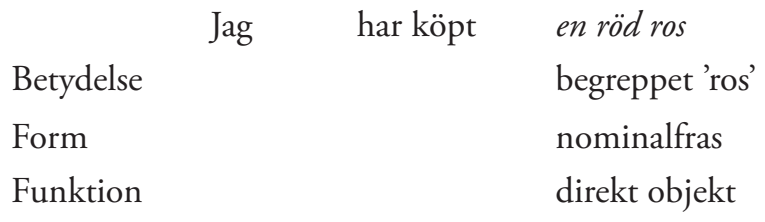

I andra satser kan samma nominalfras fungera som subjekt, exempelvis i En röd ros är vacker. Form och betydelse är identiska i de två satserna men funktionen - satsdelen - skiljer sig åt.

Att hålla isär dimensionerna betydelse, form och funktion verkar bereda betydande svårigheter för många studenter och detta återkom i materialet. Betrakta följande exempel, där frågan gällde att ange funktionen, det vill säga satsdel. I (2) anges korrekt svar (och notera då att en hängpelargon är direkt objekt och med ganska fiffiga metoder sättsadverbial); i (3) ser vi ett studentsvar:

(2) Korrekt svar:

$\begin{array}{cccc}\text { Jag har fått fram } & \text { en hängpelargon } & \text { med ganska fiffiga metoder. } \\ & \text {--predikat -- } & \text {-- direkt objekt -- } & \text {------- sättsadverbial ------ }\end{array}$

(3) Student A (kvinna):

$\begin{array}{llll}\text { Jag } & \text { har fått fram } & \text { en hängpelargon } & \text { med ganska fiffiga metoder. } \\ \text {-- predikat -- } & \text {-- nominalfras -- } & \text {------- prepositionsfras --.-- }\end{array}$

Satsdelen predikat, har fätt fram, skulle markeras, vilket studenten klarade. Men i stället för att fortsätta att ange funktion, alltså satsdelen direkt objekt för en hängpelargon, gled studenten över till att klassificera enligt form (se ovan) och kallade en hängpelargon för en nominalfras. Och i stället för att ange satsdelen sättsadverbial för med ganska fifffga metoder angav studenten återigen en formbeteckning, prepositionsfras. Studentens analysförslag visar på oförmåga att hålla isär form- och funktionsdimensionerna.

Ett annat exempel ses nedan:

(4) Korrekt svar:

Ida, Emils syster, trodde subjekt [NF] predikat som plockade mask. att Emil hade blivit en vit duva -- attribut [bisats] --direkt objekt [bisats] 
(5) Student B (kvinna):

$$
\begin{aligned}
& \text { Ida, Emils syster, trodde att Emil hade blivit en vit duva som plockade mask. }
\end{aligned}
$$

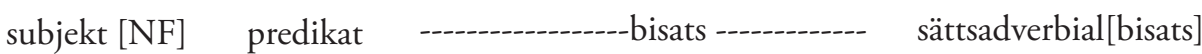

Uppgiften här handlade, som (4) visar, om att dels ange funktion, d.v.s. satsdel, dels form, markerad mellan hakparenteser. Studenten klarade av att göra detta för subjektet, som mycket riktigt har formen av en nominalfras, NF. Predikatet blev också korrekt. För det direkta objektet, att Emil hade blivit en vit duva som plockade mask, angav studenten bara formbeteckning, d.v.s. bisats, men hela bisatsen togs inte med; slutet, sekvensen som plockade mask, avskiljdes som en egen satsdel. Segmentet som plockade mask är mycket riktigt en bisats, men den är inbäddad inuti en överordnad bisats (det är en så kallad andragradsbisats, som har funktionen attribut). Detta missade studenten, som dessutom gled över till att börja tänka i semantiska banor, och kom fram till att den sista sekvensen beskrev ett sätt, vilket ledde till att som plockade mask kom att kallas sättsadverbial. Som vi kan se hade studenten i fråga kunskapsbitar som rör form, funktion och betydelse, men de olika dimensionerna blandades ihop.

Ett annat exempel på bristande förmåga att skilja dimensionerna betydelse och funktion ser vi nedan. Uppgiften gällde ordklass för de understrukna orden, i det här fallet enligt, som är en preposition:

(6) Vid Onsjö, strax utanför Larv, ligger den i folktraditionen kände "Arve i Larv"begraven, som enligt sägnen "förtalt sig mot konungen"

Student C (kvinna): enligt är adverb

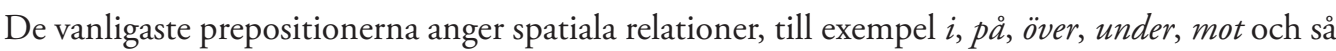
vidare. Men definitionen av språkliga enheter, t.ex. preposition, kan inte göras utifrån betydelse, utan måste göras utifrån funktion: prepositionen står i omedelbar relation med den fras som följer efter, som den "styr". I exempel (6) är detta sägnen, och därmed blir sekvensen enligt sägnen en prepositionsfras. Det faktum att enligt inte betecknar en spatial relation verkar ha förvirrat studenten, som då i stället kallade prepositionen enligt för adverb.

Svårigheter med att hålla isär dimensionerna betydelse, form och funktion nämns inte specifikt i studenternas loggböcker, men kommentarerna hos en av studenterna visar när det fungerar, nämligen när kunskaperna om de olika dimensionerna stödjer varandra: "Roligt att jobba med funktion. Kunskaperna om form hjälper verkligen vid satslösning. Tycker det flyter på bra! :) Student D (kvinna).” Det är slående att ingen annan av studenterna har kommenterat utmaningen i att hålla isär form, funktion och betydelse.

Analyser som de i (3), (5) och (6) är synnerligen vanliga i tentamina hos studenter som misslyckas i grammatiktentor. Uppenbarligen saknar dessa studenter djupförståelse av distinktionen mellan dimensionerna betydelse, form och funktion, trots att mycket tid och ansträngning ägnas åt det i undervisningen och att åtminstone vissa läromedel (exempelvis Josefsson 2009, Lundin 20I4) fokuserar kraftigt på detta. Kanske är det till och med omöjligt för en student som inte har förstått de olika dimensionerna och deras samspel att ens formulera problemet? En student som misslyckats i tentamen uttryckte sin frustration på ett ganska målande sätt: "Jag förstår inte vad det är jag inte förstår” (student E (kvinna)). Att ta sig igenom den portal som Meyer \& Land (2003) liknar tröskelbegreppen vid innebär att man ser företeelser som man inte annars ser (jfr Perkins 2008). Att hitta vägar att hjälpa studenterna att förstå vad de inte förstår 


\section{Gunlög Josefsson \& Katarina Lundin}

är en pedagogisk nyckelfråga för grammatikundervisningen. Detta kräver naturligtvis också att läraren har mycket goda och djupa grammatikkunskaper.

En intressant fråga är i vilken utsträckning svårigheten att skilja mellan betydelse, form och funktion är en kognitiv utmaning och i vilken utsträckning det beror på felaktig inlärning. Det är väl känt att man i grammatikundervisningen i tidigare stadier i skolan oftast börjar med betydelsedimensionen, vilket till exempel reflekteras i termen tingord, som ibland används i stället för substantiv (se liknande resonemang i Orsini-Jones 2008). Kanske elever tidigt i skolan helt enkelt lär sig att tänka i termer av betydelse och att de har svårt att ta sig vidare från denna överförenkling?

\section{Bristande förmåga att skilja mellan en linjär och en hierarkisk dimension}

En annan viktig insikt som krävs för att förstå grammatik är skillnaden mellan den hierarkiska och den linjära dimensionen (se även Svensson 1987). Talat och skrivet språk har alltid en linjär dimension; när vi skriver kommer orden ut i en linje, vilket är en reflex av att orden kommer "ut ur munnen" efter varandra i tidsmässig följd. ${ }^{3} \mathrm{Vi}$ kan i och för sig dra ihop sekvenser av ord när vi talar snabbt, t.ex. jasågenterä (för Jag såg inte det) men vi kan inte uttala två ord samtidigt, t.ex. inte i högra mungipan och det samtidigt i vänstra mungipan. Språkets linjära dimension är så självklar för oss att vi inte ens reflekterar över att den finns. Men språket är också hierarkiskt byggt. För det första utgörs ordsträngen av "bitar som hör ihop", till exempel de olika delarna i nominalfrasen en röd ros i exemplet ovan. Vidare är språket rekursivt och kan beskrivas med hjälp av "de ryska dockornas princip": En sats kan innehålla en sats som kan innehålla en sats och så vidare.

(7) Pelle berättade att Mia hade sagt att Jonna tyckte att Morgan var dum.

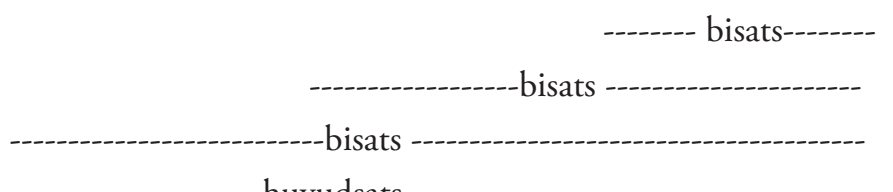

-huvudsats

I nybörjarundervisningen i grammatik på högskolenivå ägnar lärare mycket tid åt att få studenterna att förstå den hierarkiska del-helhetsprincipen. Det är alltså felaktigt att för (7) ange att huvudsatsen endast utgörs av Pelle berättade. Ofta används ett klammersystem, som illustrerades ovan, men man skulle även till exempel kunna använda ett "boxsystem", som på ett tydligt sätt illustrerar inbäddningsprincipen:

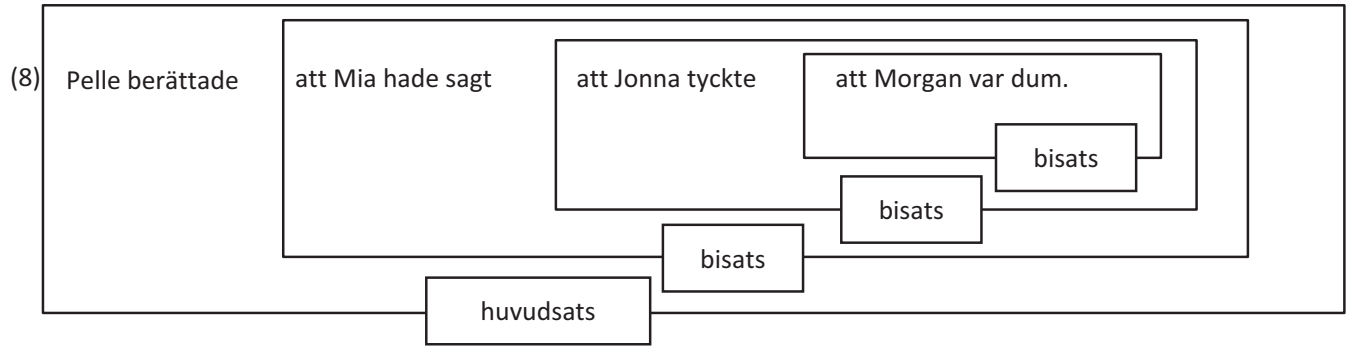

3 Även teckenspråk har en linjär dimension, men det faktum att vissa tecken kan visas samtidigt gör att kravet på linearitet är något mindre strikt för teckenspråkstalare. 
Den hierarkiska principen tycks vara svår. Se exempel nedan, där det korrekta svaret visas i (9) med hjälp av klammersystemet, och jämför med studentsvaren i (IO) och (II):

(9) Korrekt svar:

Vattenhyacinten är subjekt en vattenlevande växt som finns i tropiska Amerika. -subjektiv predikativ

(Io) Student F (kvinna):

Vattenhyacinten är en vattenlevande växt som finns i tropiska Amerika. subjekt subjektiv predikativ prepositionsobjekt

(II) Student G (kvinna):

Vattenhyacinten är en vattenlevande växt som finns i tropiska Amerika. subjekt $\quad$ FV subj. predikativ dir.obj konj IV rumsadverbial

Studenterna ger lite olika lösningsförslag, men det grundläggande problemet är att de inte ser att som finns i tropiska Amerika ingår i den större enheten en vattenlevande växt som finns $i$ tropiska Amerika. De ser, med andra ord, inte den hierarkiska del-helhetsstrukturen. Problem av detta slag är synnerligen vanliga, och vi menar att den hierarkiska principen är ett tröskelkoncept.

Om nu språket självt är hierarkiskt uppbyggt, varför är det då så svårt att se hierarkiska mönster när man gör grammatisk analys? Svaret är nog att språket är en förmåga som vi använder på ett omedelbart och oreflekterat sätt - vi kan inte förklara varför vi gör som vi gör, på samma sätt som vi kanske inte kan förklara hur vi gör när vi går och griper med händerna. Många lärare har berättat om hur de själva eller deras studenter plötsligt drabbas av insikten om det hierarkiska systemets natur - polletten ramlar ner, ibland inom loppet av bråkdelen av en sekund. Men detta händer uppenbarligen inte alla studenter - eller också tar det lång tid. Återigen skulle detta kunna bero på felaktig inlärning. Svensson (1987) visar på missförstånd i äldre språkläror, där de hierarkiska strukturerna ignoreras, och Palm (2005) visar på samma sak i modernare läroböcker för gymnasiet. Men studenternas problem skulle också kunna bero på att hierarkiska del-helhetsmodeller faktiskt är svårare att greppa kognitivt än linjära modeller, kanske för att de är kostsamma att processa. Man måste nämligen hålla mycket, ibland alltför mycket, information aktuell under hela analysprocessen. Följande exempel visar en huvudsats som innehåller en bisats med funktionen/ satsdelen direkt objekt:

(I2) Därför undrar jag

om kvalitetsarbetet lyckas.

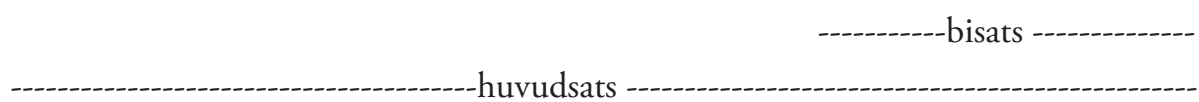

För att kunna hitta rätt i strukturen i (I2) måste man kunna identifiera huvudsatsens delar. Men för att korrekt kunna identifiera huvudsatsens delar måste man hitta och avgränsa bisatsen, som ju är en del av huvudsatsen, och sedan, när detta är gjort, gå tillbaks och relatera bisatsen till huvudsatsen. Studenterna rekommenderas i undervisningen att börja med att leta efter delarna i huvudsatsen, men kruxet är ju att detta inte kan göras utan att bisatsen först hittas, identifieras och avgränsas. Kanske sitter svårigheten i kravet på att kunna gå från helhet till del och sedan tillbaks till helheten, och att problemen åtminstone till viss del skulle kunna relateras till 
processtyngden. Den pedagogiska utmaningen ligger i så fall i att hitta möjligheter för studenterna att arbeta på ett sådant sätt och i en sådan utsträckning att processandet automatiseras.

Bristande förmåga att avgränsa satser och fraser

Ett problem som är nära relaterat till bristande förmåga att skilja mellan linjär och hierarkisk struktur är bristande förmåga att kunna avgränsa fraser och bisatser, alltså veta hur långa fraserna och bisatserna - och följaktligen satsdelarna - är. Instruktionen till frågan i (13) var att stryka under bisatserna och att ringa in bisatsinledaren. Studenterna skulle i den första meningen stryka under När solen har sjunkit så långt att en strimma syns över horisonten, och sedan ringa in bisatsinledaren När. I nästa mening skulle de stryka under bisatsen som man ser och ringa in bisatsinledaren som: ${ }^{4}$

(13) Korrekt svar:

När) solen har sjunkit så långt att en smal strimma syns över horisonten kan man ibland märka att denna skiftar färg från orange till grönt. Det sista då en stråle som blixtrar fram.

(I4) Student H (kvinna):

När) solen har sjunkit så långt att en smal strimma syns över horisonten kan man ibland märka att denna skiftar färg från orange till grönt. Det sista då en stråle som blixtrar fram.

Det ska tilläggas att inkorrekta svar som det vi ser i (I4) är vanliga. I detta har studenten hittat bisatsinledarna, alltså bisatsernas början (bisatsinledarna när och som är korrekt inringade), men hon ser inte var bisatsen slutar. Om man ser det hela från den positiva sidan kan man säga att studenten är på väg - hon ser att det finns bisatser i exemplet. Å andra sidan visar läsningen på ett globalt problem med några av de viktigaste begreppen i språkbygget - huvudsatser och bisatser. Det borde räcka att använda sin magkänsla för att se att hela När solen har sjunkit så långt att en smal strimma syns över horisonten kan man ibland märka att denna skiftar färg frän orange till grönt är en huvudsats. Det kan inte vara en bisats i och med att den kan stå för sig själv, kan följas av en ordentlig paus och uttrycker en självständig tanke, kriterier som är utmärkande för en huvudsats.

Bekymmer med avgränsning reflekteras i student I:s loggbok:

Detta med bisatser tycker jag är svårt, framför allt hur man avgränsar dem i början och i slutet. Själva kärnan i bisatsen är lätt att hitta pga inte-regeln.

Att hitta början på en bisats är ofta ganska lätt, i och med att det finns en lista på typiska bisatsinledare, som man till och med kan lära sig utantill. Mer diskussion följer nedan, där vi kommer att precisera vad vi menar med att avgränsning av fraser och bisatser är ett tröskelbegrepp.

\section{DISKUSSION}

Vi har tagit upp och diskuterat vad vi ser som tre tröskelbegrepp inom grammatikens område: distinktionen betydelse-form-funktion, den hierarkiska principen och avgränsning av fraser och satser. Låt oss granska dem lite närmare.

4 Det finns en inbäddad andragradsbisats i exemplet: att en smal strimma syns över horisonten, men vi bortser från detta i vårt resonemang. 
Distinktionen mellan betydelse, form och funktion är, menar vi, ett tydligt exempel på ett tröskelbegrepp. De flesta studenter kan resonera om formkategorier, till exempel bisats och nominalfras, liksom funktionskategorier, till exempel subjekt och predikat, under förutsättning att den aktuella dimensionen diskuteras isolerat - form för sig och funktion för sig. Problemet uppstår när analysen blir mer komplex och studenterna måste hålla de olika dimensionerna isär. För att stödja studenterna används på de aktuella kurserna olika notationssystem för form och funktion - formkategorierna noteras inom hakparentes, till exempel [nominalfras] och [bisats]. Möjligen gör en del studenter åtskillnad mellan form och funktion på ett mekanistiskt sätt, det vill säga nöjer sig med att räkna ut vilket notationssystem som de förväntas att använda, dock utan att riktigt förstå varför. Detta fungerar som metod så länge uppgifterna rör sig inom en av sfärerna, men bryter samman när en och samma mening ska analyseras enligt både form och funktion.

Att förstå det hierarkiska systemet - att fraser och satser kan innehålla fraser och satser, som i sin tur kan innehålla fraser och satser (se (8) och (9) ovan) - och relatera det till den linjära dimensionen är en verklig stötesten för många studenter. När man väl har förstått detta är det lite svårt att förstå vari svårigheten ligger. Det finns studenter som berättar om ögonblicket när de insåg att en sats i princip kan innehålla hur många satser som helst, och faktiskt såg skönheten i denna så enkla princip som samtidigt skapar möjlighet till oändlig språklig variation.

Varför är det då så svårt att se den hierarkiska strukturen? För vissa studenter kan förvisso tidigare felaktig inlärning inverka menligt (se Orsini-Jones 2008 för liknande reflektioner). En del feltyper kan möjligen bero på att tidigare felinlärning har satt spår hos inlärarna. Enligt vår mening är dock det stora problemet att den linjära strukturen är så visuellt prominent. Orden kommer ur munnen linjärt, d.v.s. efter varandra. I skrivet språk är detta ännu tydligare - orden radar upp sig prydligt på rader med mellanrum mellan varje ord. Det faktum att orden grupperar sig rekursivt syns inte i text (även om viss gruppering har motsvarigheter i prosodiska markeringar). Vi verkar vara så marinerade i språklig linearitet att vi har svårt att medvetandegöra oss om den hierarkiska.

I motsats till Orsini-Jones (2008) uppfattar inte författarna till denna artikel begreppen morfem, fras och sats i sig som tröskelbegrepp. Tvärtom menar vi att alla tre begreppen är intuitiva och lätta att förstå - enkla exempel bereder inte studenterna några problem. Att begreppen ibland kan vara svåra att tillämpa i mindre typiska fall är en helt annan sak. Vad som gör att vi menar att avgränsningen av fraser och satser är ett tröskelbegrepp är att en behärskning av förståelsen av detta kräver att studenten kan manipulera språkliga exempel genom flyttning, framför allt den metod som inom språkvetenskap kallas för topikalisering - flyttning av ett språkligt led till positionen först i satsen, före huvudsatsens finita verb. (Denna typ av språklig manipulering är delvis språkspecifik och fungerar på svenska men till exempel inte på engelska.) Grundprincipen är att endast hela fraser eller satser kan topikaliseras, med bibehållen tolkning av satsen. Om tolkningen ändras eller om resultatet blir ogrammatiskt är fras- eller satskandidaten ingen fras eller sats. Ett exempel visas nedan, där utgångspunkten är meningen Flickan gillade den röda väskan från Paris, där den röda väskan från Paris betyder 'den röda väskan som kom från Paris'. Om en student ställer upp hypotesen att den röda väskan utgör en korrekt avgränsad nominalfras i den aktuella huvudsatsen, så ska denna fras också kunna sättas först i satsen, före verbet gillade - med bibehållen betydelse. (Subjektet måste samtidigt flyttas till höger om gillade.) Den överstrukna frasen illustrerar denna "flyttningsmanipulation":

(I5) Den röda väskan gillade Marie tent röda väskant från Paris. 
Den nya meningen som är resultatet, Den röda väskan gillade Marie frän Paris kan inte knytas till betydelsen 'den röda väskan från Paris'. Följaktligen kan inte heller den röda väskan vara en fras i det aktuella exemplet, utan i stället hela den röda väskan från Paris. Hela denna fras kan ställas först i satsen med bibehållen betydelse.

(ı6) Den röda väskan från Paris gillade Marie den röda väskan från Paris.

Vi menar att kunskapen om hur man avgränsar fraser och satser med hjälp av flyttningsmanövrer är ett tröskelbegrepp. Det är först när man har lärt sig att bryta upp satser och meningar och flytta runt delarna som fras- och satsbegreppet har sjunkit in. Frasbegreppet i sig är alltså inte ett tröskelbegrepp, menar vi, i motsats till Orsini-Jones (2008), utan tanken på fraser och satser som manipuler- och fyttbara enheter. Tolkat i termer av Perkins tre kunskapstyper, possessiv, performativ och proaktiv kunskap (se ovan), skulle man kunna hävda att possessiv kunskap om fraser och satser handlar om att kunna ge en definition och ge exempel på fraser och satser, performativ kunskap handlar om att kunna hitta de vanligaste typerna i exempel, medan den proaktiva kunskapen innebär att kunna se fras- och satsstrukturen intuitivt och omedelbart - och sedan kunna använda denna kunskap för att manipulera satser bland annat genom flyttningsmanövrar, till exempel topikalisering. Den som har proaktiv kunskap har skaffat sig ett språkligt öga och ser på meningar, satser och fraser på ett annat sätt.

Till den proaktiva kunskapen inom grammatikens område ligger också förmodligen förmågan att på ett medvetet sätt skapa ogrammatiska satser, vilka man i språkvetenskaplig praxis brukar markera med en asterisk, t.ex. ${ }^{*}$ Den röda väskan från Paris Marie gillade. Många studenter upplever det som svårt och lite obegripligt att arbeta med ogrammatiska satser när man ska lära sig grammatik. Kanske är det ett exempel från grammatikens område på ett av de fyra karakteristika som kännetecknar proaktiv kunskap, att den är "troublesome"; enligt Perkins kan "troublesome" innebära "'alien', or counter-intuitive, ritualised, inert, tacit or even intellectually absurd at face value" (Perkins 1999, återgivet i Land, Meyer \& Smith 2008, s. x).

Kunskapen om språkets hierarkiska uppbyggnad är, menar vi, det viktigaste nyckelmomentet till förståelse. Om man inte förstår detta blir det också svårt att inse hur betydelse, form och funktion förhåller sig till varandra, liksom att kunna göra avgränsningar. Risken är då ganska stor att man bara tillägnar sig en associativ kunskap där grammatiska termer och begrepp svävar i ett tomrum och kopplas ihop mer eller mindre slumpmässigt. Vi tror att det är avgörande att grammatiklärarna är medvetna om dessa tröskelbegrepp, inte minst svårigheterna med den hierarkiska byggnaden och tränar studenterna i att tänka systematiskt. Knäckfrågan är hur detta görs bäst.

\section{DIDAKTISKA IMPLIKATIONER}

Hur ska man då arbeta för att hjälpa studenterna att ta sig över de trösklar som diskuterades i förra avsnittet? Undervisningen måste naturligtvis fokusera tröskelbegreppen, men vi menar att det finns andra viktiga aspekter av grammatikundervisningen som också bör lyftas upp. Här tänker vi diskutera attitydfrågan (något som också tas upp i Orsini-Jones 2008). Vi diskuterar vidare problemet med att grammatisk analys kräver att man orkar tänka "långa tankar" och klarar av att hålla flera bollar i luften samtidigt. Frågan vi ställer är i vilken utsträckning man bör låta studenterna "beta av" momenten ett efter ett eller ändra tentamensformen till hemtenta. Förenklingens svåra, men viktiga konst diskuteras vidare, och till sist ställer vi oss frågan om grammatikmomentet borde integreras i andra språkvetenskapliga moment, till exempel textanalys, ett förslag som ofta dyker upp i debatten. Vi för vår del ställer oss tveksamma till nyttan med ett sådant förfarande. 
Inför arbetet med projektet genomförde vi en gruppintervju med fyra svensklärarstudenter, där studenterna ombads diskutera vad som var svårt med grammatik. De var eniga om att grammatik var svårt - även om just dessa studenter klarat tentan vid första tillfället de skrev - men också att det var svårt att förklara vad som var svårt. Det verkar också som om själva termen "grammatik" skrämmer vissa studenter. Studenterna lyfte fram att många har med sig dåliga erfarenheter av grammatik och grammatikundervisningen från gymnasiet och tidigare skolår, och student J (kvinna) menade att

det ligger någon form utav värdering i begreppet grammatik som man liksom blockerar direkt bara man säger "grammatik", så tänker man "det här kommer vara jättesvårt, det här kommer jag aldrig klara".

Det verkar som om det finns en grupp studenter som kommer till undervisningen med dåligt självförtroende, vilket förstås riskerar att blockera deras lärande. Fenomenet är känt från till exempel matematikundervisningen. En del studenter jämför i sina loggböcker grammatiken med matematik, och tycker till och med att grammatik är svårare. I matematiken finns det "ett sätt du lär dig att systematiskt tänka om ett speciellt problem", skriver studenten, men i svensk grammatik "går det ofta att tänka i olika metodiska banor och därför blir det mer förvirrande" (student K (kvinna)). Det är inte helt tydligt vilka metodiska banor som studenten tänker på, men en rimlig tolkning är väl dimensionerna betydelse, form och funktion (se ovan). Att arbeta med attityd till ämnet är ett område där grammatikdidaktiker förmodligen har mycket att lära av matematikdidaktiker. En annan aspekt där grammatik och matematik troligen står inför samma typ av utmaning är att grammatik kräver mycket eget arbete med övningar.

En aspekt av kravet på att kunna koppla ihop olika delar av ett analyssystem är att grammatik kräver att man orkar tänka "långa tankar". En del av grammatikens utmaningar tycks vara relaterade till detta - och till en del studenters bristande förmåga att koncentrera sig längre stunder. Speciellt tydligt blir detta i tentamenssituationen. Tentamensformen för de grammatikkurser som vi fokuserar på är en salstentamen, vilket torde vara den vanligaste tentamensformen på en grammatikkurs. På så vis skiljer sig tentamensformen från många andra kurser. En iakttagelse är att studenterna förefaller ha svårigheter med att med koncentration utnyttja den tid de har till sitt förfogande. Inte sällan händer det att de lämnar in en slarvigt genomarbetad skrivning, där de möjligen har svarat på flera frågor, men där svaren både vad gäller tankeinnehåll och text är ytterst ostrukturerade. En av anledningarna till denna brist i den skriftliga framställningen är förmodligen att grammatiken kräver koncentration under en längre tid, och det orkar studenterna inte med.

Rent tekniskt kan man förstås minska ansträngningen för studenterna på olika sätt, t.ex. genom att låta grammatikkurserna löpa parallellt med andra kurser och låta studenterna göra deltentor under vägens gång. Men detta är inte odelat positivt. Att låta grammatikkursen löpa parallellt med andra kurser har prövats, men resultatet tycks varje gång bli att studenterna nedprioriterar de andra kurserna på grund av att grammatiken upplevs som så svår. Att låta studenterna tentera av mindre delar efter hand efterfrågas av några få studenter, men är inte ett allmänt krav. Studenterna skulle då tvingas "tentaläsa" vid flera tillfällen och därmed kanske välja bort att fokusera på att bygga vidare på sin kunskap och lära nytt. Grammatikmomentet skulle då också delas upp i bitar, vilket vore olyckligt med tanke på att grammatiken måste förstås som en helhet. Samma grundläggande principer är applicerbara på ord-, fras- och satsnivå - det gäller att dels förstå principerna, dels förstå hur de appliceras på de olika språkliga 
nivåerna. Och frågan är om man vinner något kvalitativt på att låta studenterna slippa undan kravet på att kunna arbeta koncentrerat. En del av själva poängen med universitetet är ju att man ska träna sig $i$ att tänka - även långa tankar - och hitta strategier för att ta till sig sådant som är svårt och utmanande.

En annan potentiell lösning för att lättare få igenom studenter skulle kunna vara att kursen tenterades genom en hemtentamen. Hemtentamen på grammatikkurser förekommer men är inte det vanliga. Inte heller detta är något som vi är odelat positiva till. Om man bortser från själva kontrollfaktorn som följer med en salstentamen, och som vi menar är viktig, är vi övertygade om att det är essentiellt att studenterna behärskar adekvat terminologi och att de vid ett och samma tillfälle kan ta fram och aktivera alla sina kunskaper för att lösa ett problem. Att kunna göra en språklig analys - av en elevtext eller någon annan text - kräver att man har förstått både de olika delmomenten och hur dessa hänger ihop, och har denna samlade kunskap aktuell. Om man blir tvungen att gå tillbaks och läsa in de olika delarna separat behöver man återigen bygga upp kunskap om delarnas relation till helheten. Vi utgår från att flertalet av studenterna faktiskt behöver kunna använda grammatiken som analysredskap för att på olika sätt arbeta med texter under sin fortsatta utbildning eller sitt yrkesverksamma liv. Därför är det nödvändigt att de förstår och utan hjälpmedel i form av litteratur kan analysera och diskutera språkliga strukturer (se Lundin 2014).

Nödvändigheten av att studenterna har god procedurkunskap och kan aktivera de olika aspekterna av grammatik ses inte minst i utredande frågor av den typ som lärarstudenterna ska besvara. Ett exempel är (I7) nedan:

(17) Din uppgift är att redogöra för svenskans verbformer och tempus samt förklara hur tempussystemen fungerar. Du ska även skriva en kort text, om 6 grafiska meningar, där du bryter mot reglerna för tempussystemen och i samband med det redogöra för vari felet består.

Uppgiften i (I7) kräver att studenterna aktualiserar det svenska tempussystemet, speciellt tanken på att det består av ett nutids- och ett dåtidssystem, och vad som karakteriserar dessa respektive system. Förutsättningen för att de ska kunna göra detta är att de har god förståelse av de grundläggande termerna. De ska därefter visa att de kan omsätta kunskapen om tempussystemet i praktiken genom att skriva sex meningar som hänger ihop i en kort text. För det tredje ska dessa meningar innehålla ett brott mot de regler som aktualiserades i början - alltså ska meningarna vara grammatiskt inkorrekta. (Under kursens gång arbetar man relativt mycket med analys av grammatiskt inkorrekta meningar, så uppgiftstypen är inte ny för studenterna.) Till sist ska studenterna beskriva de fel som de har gjort genom att applicera de regler som de aktualiserade. Uppgiften är högst relevant för svensklärare, där tempusanvändning är en central del av textbedömningen.

Många studenter har svårt för uppgifter av ovan beskrivet slag. Vår tolkning är att studenterna upplever att det är mycket stoff och information att processa på såväl perceptionssidan som produktionssidan - och de "ger upp". En enkel lösning på problemet för bedömande lärare på grammatikkursen skulle vara att underlätta för studenterna genom att formulera om frågorna och dela upp dem i olika innehållssekvenser med ett kortare svar efter varje del - men frågan är om detta motsvarar vad vi menar att de ska kunna. För att till fullo visa att man har goda kunskaper i och om grammatik krävs att man kan hålla flera bollar i luften samtidigt - eftersom språket är så komplext. Man måste kunna se, analysera och förhålla sig till alla olika språkliga nivåer samtidigt (se Josefsson 2009, Lundin 2015). Inte minst för en svensklärare är detta en högst 
relevant förmåga. Eftersom tröskelbegreppen är komplexa och förståelse av dem kräver att man kan klara av att hantera denna komplexitet menar vi att "förenklingar" av detta slag visserligen kan ge högre genomströmning på kursen, men gör att studenterna i så fall riskerar att "runda" tröskelbegreppen i stället för att ta sig över tröskeln.

Det finns dock en hel del att göra för att stödja studenterna i deras lärande. Ett sätt är att man i undervisningen kombinerar föreläsningar med genomtänkta uppgifter att utföras i mindre grupper, där det grammatiska samtalet är den viktiga komponenten. I ett projekt som rörde utvecklingen av metakognitiv förmåga inom ämnet matematik lyfter Kramarski \& Mevarech (2003, s. 282-283) fram de stora vinsterna just med att låta studenterna arbeta tillsammans i mindre grupper. De understryker dock vikten av att arbetet i grupp är strukturerat, om det ska ge studenterna möjlighet att delta i "questioning, elaboration, explanation, and other verbal communication through which students can express their ideas and group members can give and receive feedback". Ett öppet diskuterande kan kanske träna studenterna att tala om grammatik och kanske minska en eventuell grammatikskräck, men om inte samtalen leder till ett tydligt mål riskerar det att bli mer förvirrande än klargörande. Den modell som har prövats av författarna innebär såväl arbete i grupp under lärarlösa lektionspass med strukturerat material, som s.k. workshoplektioner, där ett föreläsningspass delas i två med arbete $\mathrm{i}$ grupp mellan delpassen, och där den andra av föreläsningarna baseras på det som studenterna har arbetat med. I båda fallen är uppgifterna tydligt strukturerade och målet med samtalen explicit.

Många studenter är även medvetna om hur viktigt det är att varva föreläsningar och arbete i grupp med arbete på egen hand. Det är till exempel slående hur ofta studenterna i loggböckerna skriver att de tycker sig ha förstått det viktigaste, men inser att de måste gå hem och tänka vidare - eller, vilket de också ofta skriver - sova på det hela!

Det är även viktigt att tydligt staka ut goda arbetsgångar för studenterna, inte minst att man inte kan skjuta upp en del av lärandeprocessen till senare. Även detta noterar en del studenter i loggböckerna:

Det är olika trappsteg i grammatiken. Varje trappsteg är viktigt att du upplever att du behärskar för att du ska klara grammatiken i helhet. Du kan inte tänka "jag tror jag fattar fraser nu på ett ungefär. så därför kan jag påbörja primär satslösning”. Om du till stor del upplever att inte fått in ordklasser /.../ och frasläran INNAN du påbörjar satslösningen stannar "grammatikresan" upp. (student L, kvinna)

En form av tydliggörande kan vara att läraren inför varje föreläsningstillfälle tydligt formulerar förutsättningarna, exempelvis ger specifika instruktioner om vilka kunskaper som krävs inför varje moment.

Förenklingens konst är av stor vikt inom grammatikundervisningen - liksom inom andra områden. Om man har sett att studenterna har svårt att se grammatiken som ett system måste man som lärare våga förenkla mycket i början för att lyfta fram det principiella och systematiska, även om det leder till att man ibland tvingas säga saker som egentligen inte är den fullständiga sanningen eller ens är riktigt korrekta. Studenterna kan vara behjälpta av några enkla, handfasta tumregler, även om det längre fram under kursens gång kommer att visa sig att dessa behöver problematiseras och modifieras i större eller mindre utsträckning. En student som jämförde grammatik med matematik blev glad över tumregler: 
Idag fick jag lite "formler" faktiskt att hänga upp min kunskap på. Som t.ex. den formeln att Adverb aldrig kongrueras och VPL är starkt lexikaliserade. /---/ Behövs fokuseras på dessa för mitt inlärningssystem. (student $\mathrm{M}$, kvinna)

Förenkling och tumregler ställer stora krav på förläsaren att veta vad som kan förenklas och när och hur detta kan ske. De klassiska didaktiska frågorna aktualiseras alltså även i grammatikdidaktiska sammanhang, men just här mer specifikt när det gäller möjlighet till förenklande. Men förenklandets konst är inte oproblematisk - om föreläsaren inte själv har gedigna grammatiska kunskaper riskerar undervisningen att stanna vid en förenkling, och då har man i stället gjort studenterna en björntjänst. ${ }^{5}$

Kopplat till diskussionen om förenkling finns det även ett problem med de tillrättalagda texter och meningar som studenterna ofta möter i grammatikundervisningen i ungdomsskolan. Exempel som Lisa ser en boll motsvarar inte till komplexitet, ordval eller uppbyggnad verklighetens texter - vare sig om man till verklighetens texter räknar nyhetsartiklar, elevskrivna texter eller talspråk. Problemet ligger inte i att använda tillrättalagda exempel och texter som ett led i förenklingen, men problemet uppstår om man stannar i förenklingen. En del av det motstånd och kanske den svårighet? - som studenterna verkar ha med sig när de påbörjar kurser i grammatik på universitetsnivå kan tänkas höra samman just med att de inte ser någon koppling mellan de tillrättalagda exemplen och språket de har runt omkring sig och är en del av. Något förenklat skulle man kunna säga att de inte ser sig själva som språkbrukare när det kommer till grammatiken, samtidigt som grammatiken är den absoluta förutsättningen för att de ska kunna vara just språkbrukare. Ett sätt att möjligen komma förbi problem av detta slag är att hela tiden vara tydlig med att tillrättalagda exempelmeningar är ett medel och ett redskap innan man successivt kan gå över till att arbeta med autentiska texter. Om studenterna har slipat sina analysredskap på tillrättalagt material kan de även använda dem på autentiska texter - och då kan de förhoppningsvis lättare se mening i det de gör. Den pedagogiska utmaningen är att på den tid som finns till buds skapa en brygga från de förenklade exemplen till autentiska texter, så att studenterna inser att grammatik faktiskt handlar om deras eget språk och deras egen språkförmåga.

Det kan tyckas som om grammatikmomentet är isolerat moment. Vore en integration av grammatiken med till exempel textundervisningen ett vettigt alternativ? Vi menar att en sådan integration riskerar att reducera grammatiken till ren färdighetskunskap, och det vore olyckligt. Grammatik har två sidor: dels handlar det om hur mänskligt språk är uppbyggt, med utgångspunkt i ett av de mänskliga språken, svenska, dels om hur metakunskap om detta språk kan användas i konkret arbete med språk och språklig analys. Båda delarna är omistliga. Det är sant att grammatikkursen är intensiv och på sätt och vis isolerad. Samtidigt är den djupt integrerad i resten av utbildningen genom att den belyser sådant som studenterna har arbetat med på tidigare kurser, t.ex. normer och skrivande, och grammatikkunskaperna plockas upp och används i andra kurser, framför allt i textkurser och kurser i språkhistoria och språksociologi. Vi har svårt att se poängen med ett radikalt annorlunda grepp på upplägget av grammatikkursen. Vad man däremot kan arbeta med är att inom grammatikkursens ram konsekvent för varje moment tydliggöra relevansen inom andra språkliga delområden.

5 Se Boström \& Josefsson (2006, 40-43) för en ingående diskussion om vikten av lärarnas egen kompetens för undervisningens kvalitet. 
Som de flesta lärare inom humaniora och samhällsvetenskap menar vi att alla skulle vinna på om antalet undervisningstimmar och kurslängden ökade. Det första problemet handlar om historiska principer för resurstilldelning till högskolor och universitet, det andra om att den nu förhärskande mallen för storlek på delkurser ligger på 7,5 högskolepoäng. En tendens som vi tycker oss se på olika håll i landet är att man i styrdokumenten i utbildningar av olika slag försöker tackla problemet med den svåra grammatiken med att lägga ihop grammatiken med annat, vilket i sin tur öppnar för en successiv neddragning av grammatikdelen, ibland till den grad att det är meningslöst att överhuvudtaget undervisa i ämnet. Det torde vara uppenbart att vi inte ställer oss bakom en sådan strategi.

Sammanfattningsvis kan man konstatera att det finns en faktisk svårighet med grammatik: Man måste förstå termer och deras innebörd på djupet, och man måste kunna tillämpa det man har lärt sig på autentiska texter. Ska man dessutom bli svensklärare måste man själv kunna ge undervisning i grammatik. Att tillägnandet av grammatikkunskaper är flerdimensionellt gör att det faktiskt kan beskrivas som svårt, oavsett studenternas tidigare kunskaper eller icke-kunskaper. Desto viktigare är det förstås att lärare själva har gedigna kunskaper i ämnet.

\section{FÖRFATTARPRESENTATION}

Gunlög Josefsson är professor i svenska vid Lunds universitet, men har en bakgrund som ämneslärare i svenska, religionskunskap och historia. Hennes avhandling behandlade ordbildning ur ett teoretiskt perspektiv, och huvuddelen av hennes forskning har även därefter handlat om grammatik. Hon undervisar huvudsakligen på grammatikkurser på grundnivå och avancerad nivå samt handleder studenter från kandidatnivå och upp på doktorandnivå.

Katarina Lundin är docent i nordiska språk vid Lunds universitet och har ämneslärarexamen i svenska och latin. Hennes teoretiskt inriktade avhandling behandlade satsförkortningar, men hennes forskning är numer inriktad mot språk och grammatik i bruk liksom mot utbildningsvetenskap. Hon undervisar i första hand på grammatikkurser inom olika professionsutbildningar och handleder studenter på avancerad nivå och doktorandnivå.

\section{REFERENSER}

Boström, L., \& Josefsson, G. (2006). Vägar till grammatik. Lund: Studentlitteratur.

Halliday, M. (1985). An introduction to functional grammar. London: Edward Arnold.

Josefsson, G. (2009). Svensk universitetsgrammatik för nybörjare. Lund: Studentlitteratur.

Kramarski, B., \& Mevarech, Z. R. (2003). Enhancing Mathematical Reasoning in the Classroom: The Effects of Cooperative Learning and Metacognitive Training. American Educational Research Journal, $4 \mathrm{O}(\mathrm{I}), 28 \mathrm{I}-3 \mathrm{IO}$.

Land, R., Meyer, J. H. F., \& Smith, J. (red.) (2008). Threshold concepts within the disciplines. Educational futures. Rethinking theory and practice, vol. 16. Rotterdam/Taipei: Sense Publishers.

Land, R., Meyer, J. H. F., \& Smith, J. (2008). Editor's Preface. I: R. Land, J.H.F. Meyer \& J. Smith (red.), Threshold Concepts within the Disciplines (s. ix-xi). Rotterdam: Sense Publishers.

Lundin, K. (20I4). Tala om språk. Grammatik för lärarstuderande. Lund: Studentlitteratur.

Lundin, K. (2015). Tala mera om språk. Textgenomlysning med grammatiska redskap. Lund: Studentlitteratur.

Marton, F., \& Säljö, R. (1976). On qualitative differences in learning. Outcome and process. British Journal of Educational Psychology, 46, 4-II.

Marton, F., Hounsell, D. J., \& Entwistle, N. J. (red.) (1997). The Experience of Learning (2nd Ed.). Edinburgh: Scottish Academic Press.

Meyer, J. H. F., \& Land, R. (2003). Threshold concepts and troublesome knowledge: Linkages to ways of thinking and practising within the disciplines, Improving student learning - Ten years on. OCSLD, (s. 412-424). Oxford. 


\section{Gunlög Josefsson \& Katarina Lundin}

Meyer, J. H. F., \& Land, R. (2006). Threshold concepts and troublesome knowledge: An introduction. I J. H. F. Meyer, \& R. Land (red.), Overcoming barriers to student understanding: Threshold concepts and troublesome knowledge (s. 3-18). London: Routledge.

Orsini-Jones, M. (2008) Troublesome language knowledge: identifying threshold concepts in grammar learning, I J. H. F. Meyer, \& R. Land (red.), Overcoming barriers to student understanding: Threshold concepts and troublesome knowledge (s. 213-226). London: Routledge.

Palm, K. (2005). Hierarkiproblem samt inkonsekventa och diffusa definitioner. En systematisk studie av läroböckers framställning av satsläran för årskurserna sex till nio. Magisteruppsats, Nordiska språk, Språk- och litteraturcentrum, Lunds universitet.

Perkins, D. (1999). The many faces of constructivism. Educational Leadership, 57(3), 6-II.

Perkins, D. (2008). Beyond Understanding. I: R. Land, J.H.F. Meyer \& J. Smith (red.), Threshold Concepts within the Disciplines (s. 3-9). Rotterdam: Sense Publishers.

Svensson, J. (1987). Den problematiska hierarkin. I: U. Teleman (red.), Grammatik på villovägar. Svenska språknämnden. Almqvist \& Wiksell Förlag AB.

Säljö, R. (I979). Learning in the learner's perspective. I: Some common-sense conceptions. (Report 76). Gothenburg: University of Gothenburg, Department of Education.

Teleman, U., Thelander, M., \& Andersson, E. (1999) Svenska Akademiens grammatik. Stockholm: Norstedts/Svenska Akademien. 